\title{
Correction to: Effects of Ailanthus altissima Invasion and Removal on High-Biodiversity Mediterranean Grasslands
}

\author{
Massimo Terzi $\mathbb{D}^{1} \cdot$ Diego Fontaneto $\mathbb{D}^{2} \cdot$ Francesca Casella $\mathbb{D}^{3}$
}

Published online: 23 September 2021

(c) Springer Science+Business Media, LLC, part of Springer Nature 2021

Correction to: Environmental Management https://doi.org/10.1007/s00267-021-01522-6

The original version of this article unfortunately contained a mistake. The wrong Supplementary File online resource 1 was originally published with this article; it has now been replaced with the correct file.

The original article has been corrected.

The original article can be found online at https://doi.org/10.1007/ s00267-021-01522-6.

Massimo Terzi

massimo.terzi@ibbr.cnr.it

1 Institute of Bioscience and Bioresources, National Research

Council, Bari, Italy

2 Water Research Institute, National Research Council, Verbania, Italy

3 Institute of Sciences of Food Production, National Research Council, Bari, Italy 